\title{
Girls' Familial Responsibilities and Schooling in The Gambia
}

\author{
Haddy Njie ${ }^{1}$, Caroline Manion ${ }^{2} \&$ Musukuta Badjie ${ }^{3}$ \\ ${ }^{1}$ Florida State University, Tallahassee, FL, USA \\ ${ }^{2}$ Ontario Institute for Studies in Education (OISE), University of Toronto, Canada \\ ${ }^{3}$ Action Aid International, The Gambia \\ Correspondence: Haddy Njie, Florida State University, Tallahassee, FL. 32312, USA. Tel: 1-613-947-3592. \\ E-mail: hmnjie@ncsu.edu
}

Received: April 12, 2015 Accepted: May 15, 2015 Online Published: September 27, 2015

doi:10.5539/ies.v8n10p48 URL: http://dx.doi.org/10.5539/ies.v8n10p48

\begin{abstract}
Like many countries in the developing world gender inequity remains a staggering problem in The Gambia, particularly at the secondary school level. In this study, we focus on the relationship between girls' education and heavy domestic workloads, herein referred to as girls' familial responsibilities. We explore this topic in relation not only to performance but also to the value that girls assign to schooling at the post-primary level through the use of a qualitative-inductive phenomenological-approach, mixed with descriptive survey. Findings from this study enabled us to gain a more nuanced snapshot of how, in practice, familial responsibilities can work against the goal of gender equality in and through formal education. More specifically, we find that although access to girls' schooling has improved in The Gambia, there is still a profound tension between the values parents assigned to female education and the gender socialization of the girl child in preparation for their socially expected future roles as mothers and care takers of their families. We conclude from the data that girls are allowed to attend formal schooling, but they are expected to remain feminine in and out of formal schooling spaces. Arguably, the goal for girls to remain feminine has an immediate negative effect on their schooling performances and lasting consequences on the ways they construe their opinions and values about their gender roles, social statuses and future employment capabilities.
\end{abstract}

Keywords: gender socialization, secondary education, familial responsibilities, The Gambia

\section{Introduction}

Despite considerable progress in girls' educational access worldwide over the past fifteen years, a number of issues continue to challenge global coalition, such as the Education for All (EFA) goals, for ensuring girls' retention in and successful transition through basic schooling and levels beyond it. To begin with, girls constitute over half (55\%) of all out-of-school children (World Bank, 2010). Additionally, in sub-Saharan Africa many girls continue to drop out of school before completing secondary schooling and others still are never enrolled in senior secondary school at all, where some of the greatest benefits to girls' schooling accrue (Subrahmanian, 2009; Sutherland-Addy, 2008). Moreover, in many countries in West Africa, including The Gambia, girls constitute less than $50 \%$ of the students who are enrolled in upper secondary school (see the UNESCO database, 2014). This statistical picture of girls' underrepresentation in upper secondary education is also consistent with the average for Sub-Saharan Africa as a whole, which was 44.2\% in 2012 (UNESCO, 2014).

It should be noted here that despite the aforementioned issues, the girl's education picture is not all gloomy across the different tiers of schooling. As an example, the global gender parity index for primary school enrollment was .97 in 2008 and a little higher than the index for Sub-Saharan Africa's (.91) (The edstats Newsletter, 2010). In 91 out of 162 countries, girls and boys have equal chances of graduating from primary school with a GPI that ranged from 0.97 to 1.03 (UNESCO, 2011). In The Gambia, despite the decline in girls' primary school completion rates from $82 \%$ in 2009 to $70 \%$ in 2012 , they have equal completion rates with boys in 2012 (UIS, 2014). The primary school completion rates for both genders are well below the Millennium Development Goals target of ensuring that by 2015 children everywhere, both boys and girls alike, will be able to complete six years of primary schooling, thus placing The Gambia among countries that remain far from achieving that goal.

The successes in primary school enrollment rates in The Gambia can be attributed to education policies, such as 
free and compulsory primary education, introduced in 1998 to support the goal of universal primary education, enshrined in the EFA goals. Evaluation reports have established that the policy of free and compulsory primary education adopted by The Gambia since 1998 has contributed considerably to improving girls' primary school completion (Goree Associates, 2004; Sosseh, 2012). Evidently, as is the case for other African countries, in The Gambia, the successes registered in the enrollment of girls at the basic level of schooling did not manifest the other valued education goals of ensuring girls' retention and successful transition through upper secondary and higher levels of schooling in The Gambia. Of concern now for policymakers in The Gambia are these gender disparities that continue to characterize the higher tiers of the education system in the country (Republic of The Gambia, 2010) where women constitute less than 30\% of enrolments in secondary, tertiary and vocational training in the country (African Development Bank, 2011).

The literature on barriers to girls' access to and transition through secondary education in Africa has cited a myriad of factors. These include the high cost of education, poverty and socio-cultural practices such as early marriage (Ampiah \& Adu-Yeboah, 2009; Ananga, 2011; Sutherland-Addy, 2008). The two factors of teenage pregnancy and girls' heavy domestic workload remain underexplored in the literature. In discussing gender biases and girls' educational challenges in Sub-Saharan Africa, the problem of heavy domestic workload has surfaced in numerous empirical studies (see Meena, 1996; Colclough, Rose, \& Tembon, 2000; Kea, 2007; Roby, M. Lambert, \& J. Lambert, 2009). It should be noted here that the issue is not often treated as a standalone topic. In the few cases where it is fully addressed, girls' own perspectives regarding their values for schooling, processes by which their familial responsibilities interact with their schooling experiences and the concomitant impact of that practice on their education are often obscured (see Hartmann-Mahmud, 2011; Lihwa, Johnstone, $\&$ Thomas, 2011). The current study seeks to fill this gap in our knowledge by illuminating the ways in which the gendered division of household labour is experienced and perceived by schoolgirls as a barrier to their overall schooling experiences. These experiences are then juxtaposed with the value the young women in our sample attribute to their schooling opportunities and experiences.

\section{Human Development Context of Gambian Women}

The Gambia, a former British colony, is a small, densely populated and poor country located on the West Coast of Africa. The UNDP Human Development Index ranked it at 165 th out of 187 countries in its most recent report (UNDP HDI, 2013). As a measure of educational attainment, the literacy rate for the population aged 10 years and over is estimated at 52.1 percent (Department of State for Basic and Secondary Education, 2008). The literacy level is still low among females ages 15-24, which stood at 65 percent compared to 73 percent among males (UIS, 2012). Women's low educational attainment relative to men and combined with constraints from their reproductive burden result in the concentration of a vast majority of women in informal sector jobs in developing societies (Chant \& Pedwell, 2008). In The Gambia, a majority of economically active women are employed in the informal sector, with most engaged in petty trading activities and agricultural production (Phillotte-Almeida, 1994). Moreover, Gambian women that are employed in the formal sector tend to occupy the lowest echelon in formal sector jobs (Kanteh, 2009). Ultimately, ending the vicious cycle of poverty that limits the majority of Gambian women's chances for economic prosperity and social mobility requires educational policies and programs developed with a deeper understanding of the entrenched socio-cultural practices that continue to retrogress efforts to enhance women's human's rights, dignity, and wellbeing.

Our study focuses on familial responsibilities-unpaid household labour and the gender division of it. Below present a synthesis of the literature concerning economic constraints to girls' education and dimensions of familial responsibilities, particularly girls' unpaid household labor before we elaborate on our study design and present the findings.

\section{The Literature on Girls' Education and Constraints in Sub-Saharan Africa}

\subsection{Supply Problems}

An extensive body of literature exists that has examined supply-side factors that have contributed to the poor educational attainment of girls (Leach \& Humphreys, 2007; Mirembe \& Davies, 2001; Mlama, 2005). Supply problems are associated with poor educational resources, both human and material, that affect the quality of education, including a relative lack of female role models in schools, an unsafe learning and teaching environment (i.e., gender-based violence at school) and a gender-biased curriculum. Here key supply side factors that are seen as contributing to desirable schooling outcomes for all children, include but are not limited to the provision of enough schools that are in close proximity to the communities they serve, effective teachers and appropriate learning supplies such as textbooks in sufficient supply (Handa, 2002; Tietjen \& Prather, 1991). Thus, supply factors refer to those school inputs thought of as essential for improving access to school resources for 
effective learning.

Meeting supply side factors of schooling is perhaps a critical part of strategies to enhance girls' education, but factors beyond school walls and gender dynamics and socialization within the household more specifically, can play powerful roles in shaping educational opportunities for disadvantaged individuals and groups. These factors may determine parental attitudes and responses towards education even when supply is brought to their doorsteps. For instance, if the future roles of girls are socio-culturally delimited to the categories of "wives" and/or "mothers", parents might be hesitant to invest in girls' schooling. Additionally, given the dependency on girls' unpaid labour for the functioning of households, the opportunity costs associated with sending girls' to school is high, especially for poorer households. Since the returns to schooling are often perceived to be in the distant future, parents might choose to focus on current gains they can accrue from having a female child stay home rather than have her attend school. Further, social values and beliefs can influence parents' decision on whether they will use meager financial resources on education or on meeting other basic needs.

\subsection{The Economic Factor of Family Poverty}

Numerous scholars have highlighted a number of economic reasons in their studies on the factors that result in school dropout in the context of Sub-Saharan Africa. In a recent study by Shadreck (2012) on the causes of secondary school dropout in one district in Zimbabwe, the author found that poverty and financial constraints were major reasons for students to drop out of school. Although some countries in Sub-Saharan Africa are committed to fee-free primary education in a bid to scale-up and maintain enrollment rates, the indirect (and uncovered) costs of schooling remain prohibitively high for many families. The cost of education is exorbitant in many cases due to the coupling of official with unofficial charges such as lab and fees for extra classes (Lewin, 2009). Difficulty in meeting expenses like stationeries, examination fees and school funds continues to result in students with poorer socio-economic backgrounds to drop out of school (Akyeampong, 2009; Ampiah \& Adu-Yeboah, 2009; Sifuna, 2005; Somerset, 2009).

Studies have shown that due to poverty, family's are often highly depending on children's labor for survival and this becomes a factor inextricably connected to the poor attendance, performance and school dropout cases of students from low economic backgrounds. In Africa, students of poorer family backgrounds participate in a variety of income generating activities, both agricultural and non-agricultural, in order to contribute financially to their family's wellbeing (Ampiah \& Adu-Yeboah, 2009; Ananga, 2011; Hashim, 2005).

Material poverty therefore ranks high in educational problems regarding access and retention of students, boys and girls, in schools in sub-Saharan Africa. Moreover, the precarious financial status of many families in the region keeps them highly vulnerable to economic shocks caused for example by a family member losing their job, illness or death in the family, as well as the effects of drought or other natural disasters on agricultural production. Such economic instability and vulnerability can have a negative effect on decisions to send and keep children in school in Sub-Saharan Africa. Conversely, increases in family income can have positive impacts on girls' enrollment and retention in school. Galik and Sahn's (2000), drawing on their study in Guinea, West Africa, asserted that when a household's income increases, investment in girl's education is positively affected. Their study shows no effect of household income increment on boys' schooling. These finding suggest that the negative effect of a family's financial liquidity on school enrolment may be greater for girls.

Although school fees have been abolished at the basic education level as part of Education for All policy reforms in most national education systems, and this has indubitably had a positive effect on girls' schooling, this policy shift has not been sufficiently effective in terms of addressing the myriad other ways poverty negatively impacts schooling opportunities and experiences. In Ghana as an example, Akyeampong (2009) argues that the Free and Compulsory Universal Basic Education (FCUBE) program failed in its promises because the policy did not address the high opportunity costs of schooling for the poorest households and thus did not go far enough in eliminating the economic barriers to education. Furthermore, in many sub-Saharan African countries and due to the limited financial capabilities of government, implementing a free primary education program means drawing from a limited pool of resources available for other tiers of education (Omwami \& Keller, 2010). Many countries have, nonetheless, universalized access to "free" primary schooling, a policy supported by the largest lender to education, the World Bank, but a practice that has come to be associated with inadequate and poor school resources, limited human capacity and an overall compromising of education quality in many post-colonial and aid dependent nations (Omwami \& Keller, 2010).

The literature reviewed above concerning the negative impact of economic factors on educational indicators such as enrollment, retention and educational attainments show that both boys and girls from low socio-economic backgrounds are prone to dropping out of school before reaching the last grade of secondary schooling. Girls are, 
however, less likely to be given opportunity for continued schooling relative to boys when family financial resources dwindle and/or are in short supply.

In addition to the economic factors discussed above, girls are faced with additional and distinct sets of gender barriers that can further negatively affect their educational outcomes. These factors manifest more in those spaces categorized in the literature as "socio-cultural", and in what follows we synthesize this literature in relation to girls' familial responsibilities, the focus of our study and a topic that remains under addressed in the empirical literature.

\section{The Nexus between Familial Responsibilities, Gender Socialization and Girls' Schooling Experiences}

The concept of girls' 'familial responsibilities' is used in this study to broadly refer to the slew of culturally embedded and sanctioned domestic activities that girls perform on a regular basis towards the survival of the household. In The Gambia and in other Sub-Saharan African countries, these activities span a broad range of domestic chores such as cleaning, laundry, cooking, and care of younger siblings. Girls' often are also engaged in other economic activities, including petty trading activities at home, in the market and in their neighborhoods. In this study, however, we focused exclusively on unpaid domestic familial responsibilities with the recognition that such activities are often not deemed officially as constituting "work", thus the scope and significance of them is often underestimated in official labour market statistics and analysis (Assad, Levison, \& Zibani, 2010).

For instance, about $83 \%$ of the girls interviewed confirmed that they are asked to do the stated chores because of their sex, with $69 \%$ believing that is what the Gambian society expects from them as girls and women. In the feminist literature, gender (Note 1) has been theorized as an identity marker and performance that is based on social constructions of masculinity and femininity that define "appropriate" gender roles and traits that are in turn hierarchically arranged with the effect of positioning masculine identities as superior to feminine identities (Butler, 1988). Gender is learned through socialization (Levant \& Rankins, 2014) and it is also the channel through which parents guide and mold the behaviors of their children (Marks, Lam, \& McHale, 2009).

Gender socialization involves the establishment of both implicit and explicit rules by parents that children enact in imitating their social world. These implicit and explicit rules concerning femininity and masculinity could have both immediate and lasting consequences in the ways that both boys and girls construe their opinions and values about their gender roles, social statuses (Rittenour, Colaner, Geier, \& Odenweller, 2014) capabilities and future priorities in life. As reported in studies reviewed below, gender socialization has been singled out as the most fundamental of the factors that affect the schooling outcomes of girls in Sub-Saharan African countries.

Gender roles of men and women could be conceived of as relational and complimentary and specifically in instance where both men and women contribute, within their capabilities towards the household consumption and production. However, we argue that the relationship between the two, in the light of the performance of familial responsibilities, gyrates around the axis of men control and dominance over women (Charlebois, 2010). In fact, in contemporary times and in the context of Gambian society, the shifting gender roles of women as breadwinners of their families in some households doesn't exempt them from performing their family and home care duties. Whether she is financially responsible for her family or not, she is socially expected to perform the care work because she is the subordinate sex.

The literature on barriers to girls' schooling reports that the practice of early marriage, the preservation of female chastity and the making of "competent" housewives as socio-culturally sanctioned practices and values are examples of explicit gender rules that negatively affect enrollment, retention and the education performances of girls in many African societies (Roby, M. Lambert, \& J. Lambert, 2009; Sutherland, 2008; Shabaya \& Konadu-Agyemang, 2004; Sutherland-Addy, 2008; Rihani, 2008).

Overall, the above studies have shown that girls' low schooling outcomes are frequently the result of entrenched socio-cultural practices, subsumed in the larger frame of biased gender socialization practices rather than poverty. Colclough, Rose and Tembon (2000) explored the nexus between gender inequalities and poor educational outcomes amongst girls, finding that in both Guinea and Ethiopia, gender socialization of girls as wives and mothers negatively acted upon the decisions of parents to retain their daughters in school. More recently, one of the authors of the current article in her study of gender roles and uses of literacy and numeracy among women in peri-urban Gambia with the rudiments of literacy skills observed that boys and girls were taught to perform different gender roles by mothers (Njie, 2013). In many of her study participant's households, girls were socialized at an early age into their future prescribed gender roles as mothers, by learning to tend to domestic chores. On the other hand, boys were for the most part exempted from performing activities defined as "feminine" and therefore only appropriate for girls and women. Such activities included cleaning dishes, washing laundry and cooking meals. The findings from that study indicated that gender bias practices, to the detriment of women, 
are still deeply entrenched in the cultural tapestry of Gambian society.

Studies on the socio-cultural hindrances to girls' schooling suggest that in other African countries, much like The Gambia, parents continue to expect girls to know how to effectively perform domestic chores including an assortment of activities, from the preparation of meals, to house cleaning, to laundry and the care of young children: learning how to be a good wife and mother is an important value assigned to the unpaid household labour of daughters.

Conversely, the gender socialization of boys, for the most part, excludes them from performing roles in sync with nurturing and care responsibilities. Hence, while girls are socialized into accepting their socio-culturally expected and stereotypical world of mother-crafting and domestic care manageress, boys are socialized into accepting a superior identity- as the ones to be cared for and also the ones to be in the position of control. Of course, and as shown in previous studies, in carrying out familial responsibilities, girls tend to lose valuable time from their education thus affecting their chances to succeed in their education (Lihwa, Johnstone, \& Thomas 2011; Hartmann-Mahmud, 2011). The literature on gender socialization and girls' schooling outcomes the current study draw on confirmed that greater levels of schooling deficit are associated with higher work demands on girls and that in turn, those most susceptible had a lower probability of accessing, staying in and completing their schooling.

Following gender socialization theories, the concept of "girls' familial responsibilities" is applied in the current study to demonstrate that in The Gambia, girls' schooling disadvantages are a product of a given gender system with social arrangements- both implicit and explicit gender rules- that favor men and by extension, boys as well. Further, using that concept as a framework for analyzing the intersection between gender socialization and girls' school disadvantages in The Gambia, we argue that girls' familial responsibilities mimic their expected future gender roles as mothers, housewives and overall domestic caregivers.

Despite the notable gains accrued from efforts that aim at addressing gender disparities in The Gambiaparticularly at the primary school level where there is a reverse gender disparity in enrollment, in favor of girlsour data demonstrates that girls are allowed to attend school but expected to remain feminine through schooling. Further, in balancing out familial responsibilities with those of schooling, often the demands of the latter are relegated. Our study illuminates the incessant cultural hindrance to girls' success in and through schooling despite the promising results in enrollment rates.

\section{Research Purpose and Questions}

The study sought to discern patterns that uncover girls' experiences with familial responsibilities, how their domestic work shaped their educational experiences in the greater Banjul area of The Gambia and the value they assign to schooling. Given this purpose, the study research question is framed thus: What is the nexus between value of schooling and work at home and how do schoolgirls conceptualize this relationship?

\section{Research Design}

The study proceeded through two different stages. In stage one, a qualitative approach was adopted to explore the values girls assigned to schooling and how their familial responsibilities shape their overall schooling experience. More specifically, a qualitative inductive phenomenological approach was deemed appropriate for use in this study because of the interest in study participants' perceptions as custodians of knowledge of a phenomenon that affects their lives (Creswell, 2013; Moutakas, 1994; Merriam, 2009). Moreover, we relied on this methodological tool to conduct this study because emphasis is neither on the phenomenon nor the participants, but rather on the dialogue of individuals about their lived experiences of a problem that affects them directly within their context of meaning (Moutakas, 1994).

\subsection{Data Collection}

In the first stage of the research, a purposive criterion sampling technique was used to select participants. The criteria used for identifying low income individuals included the following: (a) none of the parents of the girls interviewed worked in high government positions or had a thriving private business and (b) none of the girls interviewed had house help which could lessen the amount of time and work required of them at home, as is common in the households of more affluent families. The demographic characteristics of this sample of low income participants was accessible to one of the authors who was engaged with parents of low socio-economic status in her study of gender roles and uses of literacy and numeracy among women of low educational qualifications in The Gambia. Her insider perspective of the ways married women in her study managed their household concerning family and home care responsibilities and the familial responsibilities of their girl children towards those duties greatly aided her in selecting the girls who participated in the initial phase of this study. In 
cases where initial observation and dialogue with a parent suggested a situation where enormous familial responsibilities were assigned to a girl child who met the age criterion of the study and regardless of their academic performance, permission was sought from that parent to have her child participate in the study. Thirty girls were purposively selected from a sample of female parents who resided in the greater Banjul area and who participated in the literacy and numeracy usage study. In the second stage of the study, fifteen of the thirty girls who took part in the in-depth interviews and had expressed interest in participating in the focus group discussions were purposively selected to take part in them.

A follow up descriptive survey, based on perspectives from the qualitative data was conducted in September 2013 , by another of the authors to examine how the initial qualitative perspectives of the study participants resonate with/or not among 30 other students, drawn from two schools in the greater Banjul area. The schools were purposively selected because they were within easy reach and had previously consented to allow the researchers to invite students to participate in the study. The assumption was made that students who attend public junior schools in The Gambia are generally from lower-income households and thus, the probability of having a high percentage of students who perform domestic chores at home in public school classrooms, even with the randomization technique used, would be high.

\subsection{Data Analysis}

Inductive coding was first applied by two of the authors to capture the emergent themes and categories in our data before a deductive coding technique was developed for a more targeted data analysis, in relation to the study research questions (see Miles, Huberman, \& Saldaña, 2013). The three main categories in our code book that informed this study and based on the research questions were value for education, familial responsibilities and schooling experiences. These categories, guided by the study participants' assertions were further fleshed-out by adding sub-categories. For instance, in the case of schooling experiences, we had sub-nodes for academic performance and participation in extracurricular activities. The category of value for schooling had the sub-nodes of career goals and personal and family reasons for going to school. Familial responsibilities had attributes such as types of activities performed, family type, family environment and participants' family background based on qualitative interviews.

The descriptive survey used the Likert scale design and included the five categories of "strongly disagree", "disagree", "neutral", "strongly agree" and "agree". The survey items for each of the three constructs-value for schooling, familial responsibilities and educational experiences-were directly adopted from the qualitative interview data in order to examine the extent to which these perspectives that emerged in the qualitative data are reflective of the experiences of other groups of girls and as well as to be able to quantify them.

It must be emphasized here that, with regard to our use of descriptive survey, our goal was not to generalize results of the survey but to present, in another structured fashion, the convergence or divergence of the narratives concerning familial responsibilities and schooling experiences between the two groups of girls that participated in the study. We made judicious efforts in the qualitative analysis and reporting of findings to provide detailed individual situations and yet recognize that direct generalization is not possible from these individual stories. Direct quotations are used where necessary to exemplify a point.

Our analysis and discussion presented here is guided by the research question previously identified, in which we seek to better understand the relationship between values for schooling and work at home and how girls make sense of the relationship between the two.

The sensitive nature of the study raised salient ethical issues that had to be carefully considered during the research process. Standard informed consent procedures were followed in the recruiting of youth participants. In both groups, the informed consent form guaranteed confidentiality of the participants in the study. Therefore, anonymous names are used whenever a direct quote is drawn from the data to validate a point.

\section{Findings}

This study uncovers patterns that connect the nexus between the value(s) of schooling and work at home and how that relationship is conceptualized by the Gambian schoolgirls in our study. Summarily, from the transcription and analysis of the interviews, it is evident that the familial responsibilities of girls have some bearing, mostly negative, on their schooling experiences. This finding is consistent with reports on the negative influences of household chores on girls' schooling (Hartmann-Mahmud, 2011; Colclough, Rose, \& Tembon, 2000; Kea, 2007; Roby, M. Lambert, \& J. Lambert, 2009). Although the experiences of almost all of the girls' in this study are quite similar to what is reported in the existing literature about the effects of household chores on girls' schooling, there were some minor nuances in the experiences of some of the girls in the study. For instance, 
some of the girls complained about having to fetch water from street taps at least twice a day while others do not have to perform that chore since they have access to piped water at home, suggesting the importance of the household's location in determining the nature and scope of girls' familial responsibilities. According to an overwhelming majority of the study participants in the current study, girls' familial responsibilities do shape their overall schooling experiences in ways that are contrary to their values for education. Their experiences as they relate to the study's research questions and its three key constructs-value for education, work at home and schooling experiences- are discussed below, more thoroughly, with connections made to the existing literature as appropriate.

\subsection{Value for Education}

The study findings show instances of a lack of harmony between the values that girls assign to their schooling and their overall schooling experiences. There is high enthusiasm among the majority of girls in the study about schooling and in fact they all saw education as a means to financially support their families and themselves in the future. Table 1 below presents the qualitative testimonies of the girls regarding their values for schooling and corresponding percentages based on those qualitative assertions gathered from the descriptive survey.

Table 1. Value for schooling

\begin{tabular}{lccccc}
\hline Qualitative testimonies on girls' value for schooling & \multicolumn{5}{c}{$\begin{array}{c}\text { Descriptive survey results of the } \\
\text { qualitative testimonies }\end{array}$} \\
\hline $\begin{array}{l}\text { I am going to school because I am being forced by my } \\
\text { parents to go to school and not because I am interested } \\
\text { in schooling. }\end{array}$ & SD & D & N & SA & A \\
$\begin{array}{l}\text { I am going to school because I want to be financially } \\
\text { independent in the future by getting a good job when I } \\
\text { graduate. }\end{array}$ & 3.3 & 36.7 & & 10 & 6.6 \\
$\begin{array}{l}\text { If I am absent from school for some reason, I feel very } \\
\text { sad the whole day. }\end{array}$ & - & - & 16.6 & 26.7 & 56.7 \\
$\begin{array}{l}\text { When I miss classes, I do ask my teachers or friends to } \\
\text { explain to me the classwork I have missed }\end{array}$ & & 3.3 & 3.3 & 43.3 & 50 \\
\hline
\end{tabular}

The qualitative and survey data revealed interesting patterns regarding values for schooling. Girls are attending school without being forced by their parents or guardians. For instance, $83.4 \%$ of the girls interviewed confirmed not being forced to go to school. The findings revealed that, $93.4 \%$ of the girls interviewed do not only view education as a personal interest or desire to achieve (i.e., intrinsic values of schooling) but that education can be a means for future financial independence through gainful employment (i.e., extrinsic values of schooling) after graduation.

The majority of girls expressed a serious commitment to succeed in their schooling and in some cases they would ask for makeup classes, especially in core subjects such as English language, science, agriculture and mathematics when they miss classes. As a result, $83.4 \%$ of the girls said that they do not want to miss school or classes and that missing class makes them sad. However, not all girls' expressed a strong belief in the value of the schooling, with close to $17 \%$ agreeing that they were being forced to go to school against their wishes.

It is obvious from the percentage scores from the descriptive survey data and qualitative testimonies that the study participants assigned a high value to schooling and saw schooling as a way of gaining social mobility and economic prosperity for themselves and their families. It is interesting to note here that all the study participants who were interviewed about the reasons for their going to school mentioned helping their families as one of their primary motives behind their commitment to their studies. Investing in children's education is socially accepted and promoted as a way for parents to help ensure their children are able to support them and serve as a safety net in their elderly years.

\subsection{Familial Responsibilities}

Our findings suggest that the educational dreams of girls are being jeopardized by the amount of time and energy required of them to meet their intense familial responsibilities. One participant narrated her daily work routine thus: 
When I get up in the morning before I take a shower, I have to fetch water for cooking, cleaning and laundry. Then my sister and I will clean the yard. It is only when we finish some chores that we can go to school. After school, my sister and I have to divide the tasks again. She either cooks rice for dinner in the evening and I clean the yard or whichever she wants. The last thing we do is fetch water. This is done on a daily basis, unless when we fall sick. After we finished all the work, we get tired and cannot study for so long. (Amie, September 2012)

The above testimony is strongly echoed in the vast majority of the qualitative testimonies and results of the descriptive survey on familial responsibilities, as presented in part in Table 2 below.

Table 2. Girls' familial responsibilities

\begin{tabular}{llcccc}
\hline Qualitative testimonies on girls' familial responsibilities & \multicolumn{4}{c}{$\begin{array}{c}\text { Descriptive survey results of the } \\
\text { qualitative testimonies }\end{array}$} \\
\hline $\begin{array}{l}\text { Although I am going to school, I also have chores to perform at } \\
\text { home. }\end{array}$ & SD & D & N & SA & A \\
$\begin{array}{l}\text { I personally know of some girls attending school who have many } \\
\text { chores to do at home. }\end{array}$ & & & 10 & 53 & 36.3 \\
$\begin{array}{l}\text { I feel that household chores have negative effects on my education } \\
\text { and future career goals. }\end{array}$ & - & 10.3 & - & 53.3 & 36.4 \\
$\begin{array}{l}\text { I have to do these chores because I am female. } \\
\text { I believe chores are assigned to girls in general and not to boys } \\
\text { because girls are expected by society to do those chores. }\end{array}$ & 6.7 & 23.3 & - & 46.3 & 23.3 \\
\hline
\end{tabular}

There are evidently, and as reported in the literature reviewed above, numerous challenges that hinder girls' access to education and among them is their familial responsibilities. From the 30 respondents, about $96.6 \%$ agreed that they have chores to perform at home. The chores they have listed under the open ended question for types of chores perform at home ranged from washing dishes, cleaning the house, including toilet facilities, sweeping compound yards, taking care of children and siblings, shopping from the market (grocery shopping), and cooking. About $90 \%$ confirmed personally knowing some girls attending school who have many chores to do at home. The question becomes what effect this has on girls' education. The data showed that $89.7 \%$ of the girls confirmed that these chores negatively affect their schooling because they get tired and thus are unable to read or concentrate in class. The study further revealed that girls' familial responsibilities are gendered. For instance, about $83.3 \%$ of the girls interviewed confirmed that they are asked to do the stated chore because of their sex with $69.3 \%$ believing that is what the Gambian society expects from them as girls and women.

\subsection{Schooling Experiences}

The majority of the girls interviewed expressed that they lack enough time to focus and complete their homework and to study at home. When they return from school, most have to continue working on the household chores. In the case of girls who are going to school in the afternoon (Note 2), they spent all the morning doing the household chores, only to stop when it was time to go to school. Many girls elaborated on this topic:

The work does not allow me much time to study. I don't always do well on homework because there is not enough time to do any good work. At times I submit my homework, knowing that I could have done a better job, but really there is no time. (Ndey, October, 2012)

In as much as I am motivated to learn, at times I find it really hard to keep up with the schoolwork, particularly in the case of homework. By the time I am ready with the household chores, I am so tired and sleepy. (Fatou, October 2012)

I was doing well in my early primary school grades uh...Grades $1-4$, but since I could help out with the housework that has changed a lot. My problem is finding time to study at home. (Binta, October 2012) 
Another revealing aspect of the interference of girls' familial responsibilities on their schooling uncovered in our study concerned the negative impact of double shift schooling on girl's educational opportunities and experiences. Girls in the study who attended classes in the afternoon in the double shift schooling system narrated that they spend all the time in the morning before going to school doing household chores, as well as in the evening when they return from school thus leaving little time or energy for study. Girls enrolled in the afternoon shift shared the following experiences:

I go to school in the afternoon, so I have to help my mother in the morning to prepare the food she sells at a primary school. This takes a lot of time away from my studies. Also, after school, in the evening, I have to help her clean the utensils, bowls and plates that were used by the students for eating the food she sells. (Ida, December 3, 2012)

Since I go to school in the afternoon, I have to go to the market with my mother in the morning to get the ingredients for lunch. I would then return home and cook lunch quickly before it is time to go to school. When I was going to school in the morning, my mother used to cook at night, and all we do was warm the food up and eat when we come home after school. The burden of cooking lunch is now on me. (Binta, December 3, 2012)

The above findings are consistent with Kea's arguments in her study of girls' farm labor and double shift schooling in The Gambia, specifically that, "double shift schooling provides girls with slightly less time in school, and more opportunity for others, notably mothers and adult female farmers, to make additional use of their labor, as and when it is needed" (2007, p. 24). Chant and Touray (2013) have advanced similar arguments concerning the adverse effect of the double shift schooling system on girls.

Although our study findings confirm Kea (2007) and Chant and Touray's (2013) findings about the negative consequences of double shift schooling on the girls' education, there were some nuances. We find that that girls spending lesser number of hours in school due to the policy of double shift did offset the opportunity cost of their labor at home since they can still budget time to tend to their familial responsibilities, regardless of whether one goes to school in the morning or during the afternoon session. Arguably, the positive, unintended implication of the policy can be found is in its actual availability of time for domestic work at home and the absence of which many parents would have prevented their girl children from attending school. However, as was the case in the narratives of many of the girls in the study, tending to domestic chores takes precedence over formal schooling demands in many cases. Table 3 , below presents the qualitative testimonies of the study participants and the results of the descriptive survey regarding familial responsibilities and how these are perceived as shaping the academic experiences of the young women in the sample.

Table 3. Familial responsibilities and academic experiences

\begin{tabular}{|c|c|c|c|c|c|}
\hline $\begin{array}{l}\text { Qualitative testimonies on educational experiences and } \\
\text { familial responsibilities }\end{array}$ & & $\begin{array}{l}\text { riptive } \\
\text { qualit }\end{array}$ & vey & esults & \\
\hline My educational performance would have been better if & SD & $\mathrm{D}$ & $\mathrm{N}$ & SA & A \\
\hline I did not have to do too many chores at home. & 10 & 10 & 10 & 47 & 23 \\
\hline $\begin{array}{l}\text { I have the belief that girls would have done much better } \\
\text { in school if they did not have too much chores to do at } \\
\text { home. }\end{array}$ & 10 & 13.3 & 6.7 & 50 & 20 \\
\hline $\begin{array}{l}\text { At times, I wish I could have as much time as my } \\
\text { brothers or male cousins have to just focus on } \\
\text { schoolwork. }\end{array}$ & 20 & 6.7 & - & 40 & 33.3 \\
\hline $\begin{array}{l}\text { I feel boys have better educational performance than } \\
\text { girls in some subjects because they have more time to } \\
\text { study at home }\end{array}$ & 3.3 & - & 3.3 & 46.7 & 46.7 \\
\hline
\end{tabular}

The data in Table 3 above suggests some association between familial responsibilities and girls' academic performance. As an example, $70 \%$ of the girls declared that their schooling would have been considerably more 
effective had they not been over-burdened with so many time and labour intensive domestic chores. Although $20 \%$ of the girls did not agree with the statement about their educational performance, standing a chance to perhaps perform better at school if they had no chore to perform at home, $93 \%$ of the girls agreed that they would have performed better than boys in some subjects if they did not have as many chores to perform.

\subsection{Schooling Experiences: Opportunity to Do School Work at Home}

The familial responsibilities of girls' in the study in some cases limit the opportunities to do school work at home. On this theme, the students shared the following experiences:

I can only do my schoolwork when I finish the household chores. Otherwise, I will be called to leave whatever I was doing to do the chores. So there is of course in my case the desire to do school work but I have to finish the housework first. (Binta, December, 2012)

I do not have any free will to do my homework at the time I want it done. The school work come[s] last in the house. I can only do assignments when I am through with the house work. The problem though is that by the time I am ready to study, I am completely exhausted and all what I think of is sleeping. (Isatou, December, 2012)

I do have freedom the days I am off from the housework to do my school work without being asked to stop and finish the housework. However, I do lose this freedom when I am on duty and my sisters are off from the housework. (Fatou, December, 2012)

Although the motivation to study is present in many of the girls in the study, as reflected in the above testimonies, the lack of time to engage in schoolwork, as and when they are supposed to be done impedes their academic performance. The value of the girl-child labor in the household does certainly compete a lot with their schooling demands. Girls' desires to attend to their schoolwork are more strongly affected in negative ways in families with rigid expectations when it comes to carrying out their responsibilities. For those girls that live in strict families, failure to tend to household chores, for any reason, including to study, could result in punishment being meted on them, for example as in the following testimony: "My mum shouts at me if I don't carry out the duties assigned for me to do in the house. She expects me to do the work at the time it is supposed to be done" (Binta, December, 2012).

From some of the girls' testimonies, many parents consider the work that girls do as their informal training for becoming responsible wives in the future. The blame for having a daughter that cannot manage aspects of the household, particularly with respect to cooking, cleaning of the house and laundry, is entirely on mothers. This point is vividly expressed in the comment below:

My mother was called once to the school to discuss my school performance and also why I go to school late but she responded to the school principal that she should not tell her how to raise me and that the school training is not all what I need in life to be successful. She also said that the work she is training me to do will pay off when I get married. (Ndey, October 2012)

Implicit in the above testimony is the belief among some parents that schooling is not an all-inclusive package for girls' successes in the future. The hidden curriculum on women's reproductive gender roles (cleaning, cooking, laundry and child rearing and care) is pervasive and does often trump the positive intentions of girls for schooling as they are socialized to believe in these socially prescribed future roles. This kind of gender socialization is the very reason in which gender inequalities in The Gambia and other African countries are birthed. This point is also strongly emphasized by Meena (1990) in her work in Tanzania that suggested that by the time children enter formal schooling they have already formed most of their perceptions of their gender roles. Such perceptions are shaped by the social status which women hold in a given society and through what women transmit to the young boys and girls of their social roles (Meena, 1990, p. 45).

\subsection{Schooling Experiences: Participation in Extra Curricular Activities}

Some of the girls spoke of school as the one place where they get to have leisure time. For some of the girls in the study whose education was perceived as being negatively affected by familial responsibilities, their experiences of schooling were limited to the formal classroom lectures (participation in extracurricular activities was limited or absent all together), making schooling boring and a site of exclusion for some and/or a respite from unpaid household labour for others: 
I actually love to come to school every day because that is the time I can get to enjoy some rest. The work at home is too much and I find it there waiting for me even after I close school. (Ndey, December 2012)

I know all what I do in school is attend classes. I don't participate in any extracurricular activity. (Binta, December 2012)

If there is a program that falls on days when I am responsible for the chores, then I will not get to attend. I hate it when I miss a school activity because the following day students who attended will come to class discussing about it and then I am completely removed from that experience. It makes me feel sad. (Fatou, December 2012)

I do not participate in any of our after school activities because my mother needs me at home to do the housework. School for me is going to class and listening only to teachers. (Isatou, December 2012)

The narratives above suggest that some of the girls have transformed the physical spaces of the school to a relaxation facility. Rather than using the school as a facility for learning, the burden of work at home and the fatigue it brings is the precise reason girls' choose to use their school time for relaxation, while those exempted from performing such chores continue to actively participate in their learning. Opportunities for a holistic education are also limited by familial responsibilities and in some case, as noted by the study participants, familial responsibilities trump the importance of their participation in extracurricular activities.

\section{Discussion of the Findings and Concluding Remarks}

This research brought to light that although access to girls' education has opened up in The Gambia and that would also be true in the case of many Sub-Saharan African countries, certain socio-culturally embedded sanctioned practices and gender socialization norms of the kind examined in this study continue to impede girls' schooling. The motivation to excel in school is evidently present in the majority of the narratives of the study participants; however, included in those stories are lamentations concerning the lack of a social support system in this socio-cultural and economic context that is deemed imperative for effective and rewarding schooling experiences and outcomes.

The study has shown that familial responsibilities do play a critical role in girls' negative schooling experiences and poor outcomes as evident in the descriptive survey, individual in-depth interviews and focus group discussions.

As a contrast to findings from Colclough, Rose, and Tembon (2000) important study, Gambian girls are increasing attending school and the performance of familial responsibilities is no longer the single most important factor that negatively act upon the decisions of parents to retain their daughters at home. Our data, however, suggests that they are expected to remain feminine through schooling and part of maintaining their femininity include a mastery of domestic craftsmanship, a process that could narrow their educational attainments and limit their vision for self-actualization and participation in the world of productive work outside of domestic care.

The familial responsibilities they perform clearly reflect, for the most part, their expected future gender identities as mothers, housewives and overall domestic caregivers by The Gambian society. As the majority of the girls' maintained, domestic chores are assigned only to girls because that role is consistent with women's jobs, per the conception and expectation of Gambian society.

Our study demonstrated that girls' educational disadvantages span access issues and reside more deeply in some entrenched gender socialization practices such as the gendered domestic work. In carrying out familiar responsibilities, girls do not only loose valuable time for investment into their schooling, leading to poor educational outcome but, at the same time, their performing of those chores could severely quell their positive values for schooling as was the case with the majority of the study participants.

Further, we argue that the practice of familial responsibilities as a form of identity socialization might be a reaffirmation to girls of the values they should aspire to cultivate and roles they must be efficient in as they prepare for their expected future gender roles. As was eloquently stated above by one of the study participants' mother to the school administrators, learning how to tend to domestic chores early will pay-off for the girl child once she is married. Consequently, some girls are being socialized into their prescriptive future gender roles and hence the narrowing of their human capabilities particularly with respect to their future participation in the world of work outside of the domestic sphere. 
Combating economic issues to low schooling enrollment, attendance and retention through fee free education have proven to be essential strategies for advancing the cause of girls' education. Despite gains accrued from such initiatives we argue, based on evidence from the current study and previous research, that free education alone does not eradicate gender inequalities such as those that manifest in the gender division of unpaid household tasks and that impede girls' educational opportunities and experiences. Hence, in order to address issues affecting girls schooling in The Gambia and other Sub-Saharan African countries with similar challenges, deeper and underlying cultural practices such as girls spending more time than boys on familial responsibilities, should continue to be at the center of policy dialogue, albeit with a more heightened interest in neutralizing gender roles and gender power relationships.

The Forum for African Women Educationalists, Gambia chapter (FAWEGAM) and other national FAWE chapters in other African countries has been active in their use of a myriad of strategies to advance girls' schooling. For example, FAWEGAM-sponsored Mother's Clubs aim to end all cultural impediments that continue to negatively affect girl's education, is notable in this regard. That glorious goal is, however, best accomplished by introducing discussions about the fundamental human rights of girls to be accorded equally the rights and privileges that boys have access to and take pleasure in participating in simply because of their gender. Sustainable change in attitudes and perceptions concerning the value of women and their human development in and out of schooling is perhaps best attainable through the challenging of prevailing gender-biased societal norms and values that perceive girls only in the light of future domestic caregivers and housewives.

The context of formal schooling provides a relevant platform for education policy makers, practitioners in the field and parents to negotiate gender roles and gender power relationships that favor boys and girls equally. If boys and girls are held to the same standards with regard to in-school processes that measure their academic competencies, then it is only fair that familial responsibilities, which limits girls' schooling attainments, is equally balanced and distributed between girls and their male siblings. Unfortunately, in many cultures in Sub-Saharan Africa, boys can generally plunge straight into their homework and study for exam while at home but girls, for the most part, have to complete their domestic chores first before participating in such school-related activities. This different gender socialization for boys and girls can lead to disparity not only in educational outcomes but future employment opportunities in favor of boys.

Patterns from individual interview and focus group narratives suggest that the burden of familial relationship on participation in schooling was more acute for those girls who live in an extended family set-up and where numerous contenders seek out their labors. Additionally, the time child spent on domestic work was also found to be a significant predictor of whether a child will participate or not in curricular activities as an integral component for a child's schooling experience. The narratives of the girls in this study suggest that those who work for long hours or have extensive and intensive familial responsibilities were more withdrawn from their schooling experience than those individuals that had only few chores.

The availability of infrastructure such as water supply is an important factor in understanding how girls' familial responsibilities continue to work against the goal of gender equality in education. In the case of girls who live in large families, fetching the number of containers needed for their families to carry out daily activities in which the use of water is indispensable often result in going to school late or not at all. Hence, the provision of amenities such as pipe water, in close proximity to poor neighborhoods, might greatly offset the time that girls use in providing such an indispensable household need for their families.

In rigid gender systems in Sub-Saharan Africa, girl's "familial responsibilities" is, however, just one of the many explicit role identities that girls learn from the social environment where those roles are enacted. Biased gender roles can bear negative long-term consequences on girls' human capabilities in the areas of accessing good jobs with decent wages and successful career mobility within formal sector employment.

\section{References}

African Development Bank. (2011). The Gambia country gender profile. Retrieved October 1, 2010, from http://www.afdb.org/fileadmin/uploads/afdb/Documents/Project-and-Operations/GAMBIA\%20Gender\%20 Profil $\% 20$ final\%20(2).pdf

Akyeampong, K. (2009). Revisiting free compulsory universal basic education (FCUBE) in Ghana. Comparative Education, 45(2), 175-195. http://dx.doi.org/10.1080/03050060902920534

Ampiah, J. G., \& Adu-Yeboah, C. (2009). Mapping the incidence of school dropouts: A case study of communities in Northern Ghana. Comparative Education, 45(2), 219-232. http://dx.doi.org/10.1080/03050060902920625 
Ananga, E. D. (2011). Typology of school dropout: The dimensions and dynamics of dropout in Ghana. International Journal of Educational Development, 31(4), 374-381.

Assaad, R., Levison, D., \& Zibani, N. (2010). The effect of domestic work on girls' schooling: Evidence from Egypt. Feminist Economics, 16(1), 79-128. http://dx.doi.org/10.1080/13545700903382729

Butler, J. (1988). Performative acts and gender constitution: An essay in phenomenology and feminist theory. Theatre Journal, 40(4), 519-531.

Canagarajah, S., \& Coulombe, H. (1998). Child labor and schooling in Ghana. Policy Research Working Paper no. 1844. The World Bank: Washington D.C.

Chant, S., \& Pedwell, C. (2008). Women, gender and the informal economy: An assessment of ILO research and suggested ways forward. Retrieved from http:/www.cpahq.org/cpahq/cpadocs/wcms091228.pdf

Chant, S., \& Touray, I. (2012). Gender in The Gambia in retrospect and prospect. GAMCOTRAP Working Paper No. 1. Retrieved from http://www.gamcotrap.gm/content/images/stories/documents/Chant_Touray.pdf

Colclough, C., Rose, P., \& Tembon, M. (2000). Gender inequalities in primary schooling: The roles of poverty and adverse cultural. International Journal of Educational Development, 20(1), 5-27.

Creswell, J. W. (2013). Research design: Qualitative, quantitative, and mixed methods approaches. London: Sage Publications Incorporated.

De Lange, A. (2009). Gender dimensions of rural child labor in Africa. Paper presented at the FAO-IFAD-ILO Workshop on Gaps, Trends and Current Research in Gender Dimensions of Agricultural and Rural Employment: Differentiated pathways out of poverty.

Felton, S., \& Haihambo-Muetudhana, C. (2002). Girls' education in Rundu educational region: A report on a field assessment. Ministry of Basic Education, Sport and Culture, Republic of Namibia.

Gambia Women's Organization. (2011). The country profile. Retrieved from http://gambiawomen.org/the-gambian-women/

Glick, P., \& Sahn, D. E. (2000). Schooling of girls and boys in a West African country: The effects of parental education, income, and household structure. Economics of education review, 19(1), 63-87.

Goree Associates. (2004). Evaluation of Scholarship Trust Fund. Retrieved from http://www.unicef.org/evaldatabase/files/FINAL_REPORT_-_FAWE_Evaluation_-_Girls_Education_Proje ct_-_06Sept2012.pdf

Handa, S. (2002). Raising primary school enrolment in developing countries: The relative importance of supply and demand. Journal of Development Economics, 69(1), 103-128.

Hartmann-Mahmud, L. (2011). Pounding millet during school hours: Obstacles to girls' formal education in Niger. The European Journal of Development Research, 23(3), 354-370. http://dx.doi.org/10.1057/ejdr.2011.6

Hashim, I. M. (2005). Exploring the linkages between children's independent migration and education: Evidence from Ghana. Sussex Centre for Migration Research, Working Paper T12.

Hunt, F. (2008). Dropping out from school: A cross-country review of the literature. Create pathways to access. Research Monograph, No. 16.

Kadzamira, E., \& Rose, P. (2003). Can free primary education meet the needs of the poor? Evidence from Malawi. International Journal of Educational Development, 23(5), 501-516. http://dx.doi.org/10.1016/S0738-0593(03)00026-9

Kanteh, O. (2009). Presentation of The Gambia. Paper presented at the Conference on Strengthening Women's Capacities in Administration, Governance and Leadership, Tangier, Morocco.

Kea, P. (2007). Girl farm labor and double-shift schooling in The Gambia: The paradox of development Intervention. PRUS Working Paper no. 39. Retrieved from http://www.sussex.ac.uk/Units/PRU/wps/wp39.pdf

Leach, F., \& Humphreys, S. (2007). Gender violence in schools: taking the 'girls-as-victims' discourse forward. Gender and Development, 15(1), 51-65.

Levant, R. F., \& Rankin, T. J. (2014). The gender role socialization of boys to men. In R. J. Burke, \& D. A. Major (Eds.), Gender in Organizations: Are Men Allies or Adversaries to Women's Career Advancement? 
(pp. 55-72). Northhampton, Massachusetts: Edward Elgar Publishing Limited.

Lewin, K. M. (2009). Access to education in Sub-Saharan Africa: Patterns, problems and possibilities. Comparative Education, 45(2), 151-174.

Lihwa, F., Johnstone, C., \& Thomas, M. A. (2011). Kuchota maji: Educational effects and community perceptions of girls'workload in rural Tanzania. Paper presented at the annual meeting of the 55th Annual Conference of the Comparative and International Education Society, Montreal, Quebec, Canada

Marks, J. L., Lam, C. B., \& McHale, S. M. (2009). Family patterns of gender role attitudes. Sex roles, 61(3-4), 221-234.

Meena, R. (1996). Situational analysis of education of girls/women in Tanzania. UTAFITI (New Series), 3(2), 39-90.

Merriam, S. B. (2009). Qualitative research: A guide to design and implementation. John Wiley \& Sons.

Miles, M. B., Huberman, A. M., \& Saldaña, J. (2013). Qualitative data analysis: A methods sourcebook. London: SAGE Publications Incorporated.

Mirembe, R., \& Davies, L. (2001). Is schooling a risk? Gender, power relations, and school culture in Uganda. Gender and Education, 13(4), 401-416. http://dx.doi.org/10.1080/09540250120081751

Mlama, P. (2005). Pressure from Within: The Forum for African Women Educationalists. In N. Rao, \& I. Smyth (Eds.), Partnerships for girls' education. Dorset, UK: Oxfam.

Mohanty, C. T. (1988). Under Western eyes: Feminist scholarship and colonial discourses. Feminist Review, 30, 61-88.

Moustakas, C. (1994). Phenomenological research methods. Thousand Oaks, CA: Sage Publications, Inc.

Njie, H. (2013). Literacy uses and women's gender roles: Ethnography of local practices in peri-Urban Gambian community (Unpublished doctoral dissertation). Florida State University, Florida, United States.

Omwami, E. M., \& Keller, E. J. (2010). Public funding and budgetary challenges to providing universal access to primary education in sub-Saharan Africa. International Review of Education, 56(1), 5-31. http://dx.doi.org/10.1007/s11159-009-9149-9

Owusu-Banahene, N. O. (2000). The impact of custom and tradition in educating the female-child in the Sub-Saharan Africa: A case study in Ghana. Retrieved from http://files.eric.ed.gov/fulltext/ED460325.pdf

Phillot-Almeida, R. A. (2004). Profile of the roles of women as economic producers and family supporters in The Gambia. UNESCO Regional Office, Dakar.

Republic of The Gambia. (2010). Level of achievement of the Millennium Development Goals (MDGs) MDG status report 2009. Banjul, The Gambia: Gambia Bureau of Statistics.

Rihani, M. A. (2006). Keeping the promise: 5 benefits of girls' secondary education. Washington, DC, AED Global Learning Group. Retrieved from http://files.eric.ed.gov/fulltext/ED500794.pdf

Rittenour, C. E., Colaner, C. W., \& Odenweller, K. G. (2014). Mothers' identities and gender socialization of $\begin{array}{llll}\text { daughters. } & \text { Southern } & \text { Communication } & \text { Journal, }\end{array}$ http://dx.doi.org/10.1080/1041794X.2014.895408

Roby, J. L., Lambert, M. J., \& Lambert, J. (2009). Barriers to girls' education in Mozambique at community and household levels: An exploratory study. International Journal of Social Welfare, 18(4), 342-353.

Shabaya, J., \& Konadu-Agyemang, K. (2004). Unequal access, unequal participation: some spatial and socio-economic dimensions of the gender gap in education in Africa with special reference to Ghana, Zimbabwe and Kenya. Compare, 34(4), 395-424.

Shadreck, M. (2012). Quality rural secondary school education in Zimbabwe: Challenges and remedies. Journal of Emerging Trends in Educational Research and Policy Studies (JETERAPS), 3(5), 768-774.

Sifuna, D. N. (2005). Increasing access and participation of pastoralist communities in primary education in Kenya. International Review of Education, 51(5-6), 499-516. http://dx.doi.org/10.1007/s11159-005-8260-9

Singh, R. D., \& Mathew J. M. (1987). The value of work-at-home and contributions of wives household service in polygynous families: Evidence from an African LDC. Economic Development and Cultural Change, 35(4), 743-65.

Somerset, A. (2009). Universalizing primary education in Kenya: The elusive goal. Comparative Education, 
45(2), 233-250. http://dx.doi.org/10.1080/03050060902920807

Sosseh. A. (2012). Evaluation of the Girls' Education Project of the Forum for African Women Educationalists-The Gambia (FAWEGAM). Retrieved from http://www.unicef.org/evaldatabase/files/ FINAL_REPORT_-_FAWE_Evaluation_-_Girls_Education_Project_-_06Sept2012.pdf

Subrahmanian, R. (2008). Gender in primary and secondary education: A handbook for policymakers and other stakeholders. London, UK: Commonwealth Secretariat.

Sutherland-Addy, E. (2008). Gender equity in junior and senior secondary education in Sub-Saharan Africa (No. 140). World Bank Publications.

Swainson, N. (1995). Redressing gender inequalities in Education: A review of constraints and priorities in Malawi, Zambia and Zimbabwe. London: The British Development Division in Central Africa of the Overseas Development Administration.

The edstats Newsletter. (2010). The World Bank Education Statistics Newsletter, Millennium Development Goals (MDG) Special Edition, IV(1) (pp. 1-11). Retrieved from http://www.youth-employment-inventory.org

Tietjen, K., \& Prather, C. (1991). Educating girls: Strategies to increase access, persistence, and achievement. Agency for International Development (IDCA), Washington, DC. Office of Women in Development.

UNDP. (2013). Human Development Report Explanatory Note on 2013 HDR Composite Indices for The Gambia. Retrieved August 19, 2013, from http://hdrstats.undp.org/images/explanations/GMB.pdf

UNESCO Institute of Statistics Data Center. (2014). Education. Retrieved from http://data.uis.unesco.org

Volpp, L. (2000). Blaming culture for bad behavior. Yale Journal of Law \& Humanities, 12, 89-116.

World Bank. (2010) Girl's education: Key issues. Retrieved from http://www.worldbank.org/en/topic/education/brief/girls-education

\section{Notes}

Note 1. Our theorization of household chores and other home care responsibilities in this study as a gendered practice is not motivated by the desire to essentialize a particular cultural practice as the "other", a fundamental criticism of Western feminists' scholarship on Third World women (See Hirschmann, 1998; Mohanty, 1988; Volpp, 2000). Rather, this study seeks to uncover the sex-subordinating practice of the culture in which two of the authors were brought up and the effect of that practice on girl's schooling experiences and outcomes as reported by the study participants. Further, we recognized that women's subordination is a global problem that manifest in different forms and across a multiplicity of cultures. The construction of what could be dubbed "otherness" in this study is, conceptually, a meaningful attempt at interpreting the world and women's social, economic and political positions within it. As Mohanty (2014) poignantly stated, this noting of difference-particularly the kind that explains structural economic inequalities-allows feminist researchers to theorize universal (feminist) concerns more comprehensibly.

Note 2. A policy of double shift schooling means that some children go to school only in the mornings and others only in the afternoons due to high demand for schooling and lack of capacity to enrol all students in the traditional-morning through afternoon-schooling schedule.

\section{Copyrights}

Copyright for this article is retained by the author(s), with first publication rights granted to the journal.

This is an open-access article distributed under the terms and conditions of the Creative Commons Attribution license (http://creativecommons.org/licenses/by/3.0/). 